\title{
Polymorphisms of PRLR and FOLR1 genes and association with milk production traits in goats
}

\author{
J.X. Hou, F. Fang, X.P. An, Y. Yan, T. Ma, P. Han, F.X. Meng, Y.X. Song, \\ J.G. Wang and B.Y. Cao \\ College of Animal Science and Technology, Northwest A\&F University, \\ Yangling, Shaanxi, China \\ Corresponding authors: B.Y. Cao \\ E-mail: caobinyun@yahoo.com.cn / caobinyun@126.com
}

Genet. Mol. Res. 13 (2): 2555-2562 (2014)

Received December 11, 2012

Accepted October 15, 2013

Published January 24, 2014

DOI http://dx.doi.org/10.4238/2014.January.24.1

\begin{abstract}
We investigated the polymorphisms of PRLR and FOLR1 genes in Xinong Saanen, Guanzhong, and Boer goat breeds by DNA sequencing and PCR-RFLP. Two novel SNPs were identified: KC109741: g.62130C $>\mathrm{T}$ in the 3'-UTR of goat gene PRLR, and KC136296: g.7884A>C in exon 3 of goat gene FOLR1. In the three goat breeds, the polymorphism information content was $0.20-0.27$ at the g. $62130 C>T$ locus. At the $g .7884 A>C$ locus, it was 0.36 in Boer goats. The three goat breeds were in Hardy-Weinberg disequilibrium at the $g .62130 C>T$ locus. The g.62130C $>\mathrm{T}$ SNP was found to be significantly associated with milk production traits in Xinong Saanen and Guanzhong breeds. These results are consistent with the regulatory function of PRLR in mammary gland development, milk secretion, and expression of milk protein genes; they extend the spectrum of genetic variation of the goat PRLR gene, which could be useful for breeding programs.
\end{abstract}

Key words: SNP; PCR-RFLP; PRLR; FOLR1; Genotype 


\section{INTRODUCTION}

Prolactin receptor (PRLR) belongs to the same family as the growth hormone receptor and is part of the cytokine receptor superfamily, characterized by its ability to activate JAK2 and three members of the Stat family, Statl, Stat3, and Stat5 (Clevenger et al., 1998). There are two distinct PRLR isoforms, produced by alternative splicing of the primary transcript: the long isoform has 581 amino acids and the short one has 296 amino acids (Viitala et al., 2006). The short form is unable to mediate transcriptional activation via the JAK2/STATs pathway, which inhibits the long form-mediated activation of JAK2 and transcription by the formation of heterodimers (Bole-Feysot et al., 1998; Clevenger and Kline, 2001). The long isoform of PRLR binds prolactin and contributes to the activation of JAK2 kinases and subsequent phosphorylation of STAT5 transcription factors, which bind to recognition sequences located in promoters of milk protein genes (Bole-Feysot et al., 1998). From an animal breeding perspective, polymorphisms of the PRLR gene have been associated with fiber and reproductive traits in goats, pigs and sheep (Terman, 2005; Chu et al., 2007; Zhou et al., 2011), as well as with milk production traits in dairy cattle (Iso-Touru et al., 2009). The PRLR gene has been mapped on bovine and goat chromosome 20 (Hayes et al., 1996). A segregating quantitative trait locus (QTL) for milk yield traits on bovine chromosome 20 has been found in a few dairy breeds (Fontanesi et al., 2007). The folate receptor (FOLR), also known as the folic acid binding protein, binds 5-methyltetrahydrofolate (5-MeTHF) with high affinity (Tian et al., 2012). The folate receptor gene family includes four members (FOLR1, FOLR2, FOLR3, and FOLR4), whose encoded products bind folic acid with high affinity (Leamon and Jackman, 2008). FOLR1 and FOLR2 encode glycosyl phosphatidylinositolanchored endocytic receptors found to be expressed in some epithelial tissues (Ross et al., 1994). Folate receptor $\alpha$ (FOLR1) has shown the greatest change in gene expression in three species [12.7-fold in cow $(\mathrm{N}=3), 15.4$-fold in fur seal $(\mathrm{N}=1)$, and 2.4-fold in tammar $(\mathrm{N}=$ 4)] during periods of increased milk protein production (Menzies et al., 2009), agreeing with previous reports that folate is important for milk protein synthesis and suggesting FOLR1 as a key regulator of folate metabolism for milk protein synthesis in the mammary gland. Advances in this knowledge not only give us insight into milk production in dairy goats but also provides helpful information to dissect the candidate genes in Capra hircus and improve milk production, in quantity and quality, through genetic manipulation. On the basis of the above considerations, we detected the polymorphisms of caprine PRLR and FOLR1 genes in three goat breeds and investigated the associations between genetic marker and milk production traits. This study provides some useful information on goat genetic resources and breeding.

\section{MATERIAL AND METHODS}

\section{DNA samples and milk traits}

Genomic DNA samples were obtained from 711 goats belonging to three breeds: Xinong Saanen goat ( $\mathrm{SN} ; \mathrm{N}=323$ ), Guanzhong goat (GZ, $N=197)$, and Boer goat (BG; $N=191$ ). They were reared in Qianyang, Zhouzhi, and Liuyou counties of Shaanxi Province, respectively. All diets were based on alfalfa, corn silage, and a combination of concentrates including corn, soya meal, and bone meal. Health, fertility, and production records were maintained by 
the dairymen and veterinarians. Milk yields from first to third lactation were standardized to 300 days in milk. For milk analysis, a milk sample was taken from each animal once a month throughout lactation, sampling at least 20 days after parturition to exclude the risk of contamination with colostrum. Goats were milked twice a day at constant intervals and a $10-\mathrm{mL}$ sample from each milking session was mixed for the analysis. Milk constituents (protein and fat) were determined with an ultrasonic S60SEC milk analyzer (Milkotronic Company, Nova Zagora, Bulgaria). Five milliliters blood per goat were collected aseptically from the jugular vein and kept in a tube containing ACD anticoagulant (citric acid:sodium citrate:dextrose - 10: 27: 38). All samples were sent to the laboratory in an ice box. The genomic DNA was extracted from white blood cells using the standard phenol-chloroform extraction protocol (Santos et al., 2010; Ghaffariyan et al., 2012). All experiments were performed in accordance with the National Institute of Health Guide for the Care and Use of Laboratory Animals.

\section{Polymerase chain reaction (PCR) amplification and SNP investigation}

According to the bovine PRLR and FOLR1 genes (GenBank accession Nos. NC_007318 and AC_000172), four pairs of primers were designed to amplify the 3'-UTR and exons 2 and 3 of goat the PRLR and FOLRI genes (Table 1). Their optimal annealing temperatures are showed in Table 1. Herein, we screened them for identifying SNPs of those genes by DNA pooling sequencing assay (Bansal et al., 2002). Five microliters DNA (100 ng/ $\mu \mathrm{L})$ per sample were collected to create a DNA pool for each goat breed. PCR products were sent to Beijing Genomics Institute (Beijing, China) to be sequenced in both directions. Discovery of SNPs was conducted using the Chromas 2.31 and the DNAstar 7.0 software.

Table 1. Primer sequences for goat $P R L R$ and FOLR1 genes applied for screening polymorphisms and genotyping.

\begin{tabular}{|c|c|c|c|c|}
\hline Primer & Sequence $\left(5^{\prime} \rightarrow 3^{\prime}\right)$ & Gene region & Amplicon (bp) & $\operatorname{Tm}\left({ }^{\circ} \mathrm{C}\right)$ \\
\hline PRLR-F1 & AGAAGAACCAGCCAAGAAG & 3'-UTR & 349 & 52 \\
\hline PRLR-R1 & CACACAAGATGGAACGATTT & & & \\
\hline PRLR-F2 & AGTGAGAGTTATGGAAGGATG & 3'-UTR & 443 & 55 \\
\hline PRLR-R2 & AAGGTTAAGCAACTGGTCTT & & & \\
\hline FOLR1-F1 & CCAGGAAGGTATTGTCTCAA & Exon 2 & 499 & 58 \\
\hline FOLR1-R1 & GCTCTAGGCATTGTTCTGA & & & \\
\hline FOLR1-F2 & GTTCCTCCACCTGATGTT & Exon 3 & 414 & 54 \\
\hline FOLR1-R2 & CCTCCTCAGACCAGAATT & & & \\
\hline
\end{tabular}

The SNPs of the PRLR and FOLR1 genes were genotyped by PCR-restriction fragment length polymorphism (RFLP). The $25-\mu \mathrm{L}$ volume contained $50 \mathrm{ng}$ genomic DNA, 12.5 $\mu \mathrm{L} 2 \mathrm{X}$ reaction mix (including $500 \mu \mathrm{M}$ of dNTP each; $20 \mathrm{mM}$ Tris-HCl, $\mathrm{pH} 9 ; 100 \mathrm{mM} \mathrm{KCl}$; $3 \mathrm{mM} \mathrm{MgCl} 2), 0.5 \mu \mathrm{M}$ of each primer, and $0.5 \mathrm{U} \mathrm{Taq}$ DNA polymerase. The cycling protocol was 5 min at $95^{\circ} \mathrm{C}, 35$ cycles of denaturation at $94^{\circ} \mathrm{C}$ for $30 \mathrm{~s}$, annealing at $\mathrm{X}^{\circ} \mathrm{C}$ (Table 1 ) for $30 \mathrm{~s}$ and extension at $72^{\circ} \mathrm{C}$ for $35 \mathrm{~s}$, with a final extension at $72^{\circ} \mathrm{C}$ for $10 \mathrm{~min}$. PCR products $(5 \mu \mathrm{L})$ of different primer pairs were mixed with $0.7 \mu \mathrm{L} 10 \mathrm{X}$ buffer, $2.5 \mathrm{U}$ restriction enzyme (NEB, Ipswich, UK) and $3.8 \mu \mathrm{L}$ sterilized $\mathrm{ddH}_{2} \mathrm{O}$, and then incubated for $1.5 \mathrm{~h}$ at $37^{\circ} \mathrm{C}$. The restriction enzymes are shown in Table 2. Digestion products were subjected to horizontal $3.5 \%$ agarose gel electrophoresis. The agarose gels were stained with ethidium bromide, and the genotypes were then determined. 


\section{Analysis of microRNA sites}

The effects of allele substitution on microRNA binding sites were analyzed using the MicroInspector software (Rusinov et al., 2005).

\section{Statistical analysis}

The allelic frequencies, heterozygosity $\left(H_{\mathrm{E}}\right)$ and the polymorphism information content (PIC) were calculated using Popgene (version 1.31). Association analyses between PRLR genotypes and dairy traits were performed with the SPSS 16.0 software. Multiple comparisons of the means were performed using the least significant difference method. Data were analyzed with the following mixed linear model for SNPs and traits: $Y_{\mathrm{ikm}}=\mu+G_{\mathrm{i}}+N_{\mathrm{K}}+$ $E_{\mathrm{ikm}}$, where $Y_{\mathrm{ikm}}$ is the trait measured on each of the ikmth animal, $\mu$ is the overall population mean, $G_{\mathrm{i}}$ is the fixed effect associated with the ith genotype, $N_{\mathrm{k}}$ is the fixed effect associated with kth number of kids born, and $E_{\mathrm{ikm}}$ is the random error. Effects associated with farm, birth year, and season of birth are not matched in the linear model, since the preliminary statistical analyses indicated that these effects did not have a significant influence on variability of traits in the populations analyzed.

\section{RESULTS}

\section{Polymorphisms of goat PRLR and FOLR1 genes}

Sequencing of the amplicons of different primer pairs identified two polymorphic nucleotide sites in the goat PRLR and FOLR1 genes (Figures 1 and 2). The PCR product of the PRLR-F2 and PRLR-R2 primer pair had a g.62130C $>$ T mutation, which was in the 3'UTR of the goat PRLR gene (GenBank accession No. KC109741). The g.7884A $>$ C synonymous mutation was in exon 3 of the goat FOLR1 gene (GenBank accession No. KC136296), which was only found in BG goats. The bands of different genotypes are shown in Figures 3 and 4. In the three goat breeds, PIC was 0.20-0.27 at the g.62130C>T locus (Table 2). At the $g .7884 A>C$ locus, PIC was 0.36 in BG goats (Table 2). The genotypic distribution and allelic frequencies of the two SNPs are shown in Table 2. It was shown that the three goat breeds were in Hardy-Weinberg disequilibrium at the g.62130C $>T$ locus $(\mathrm{P}<0.05)$ (Table 2).

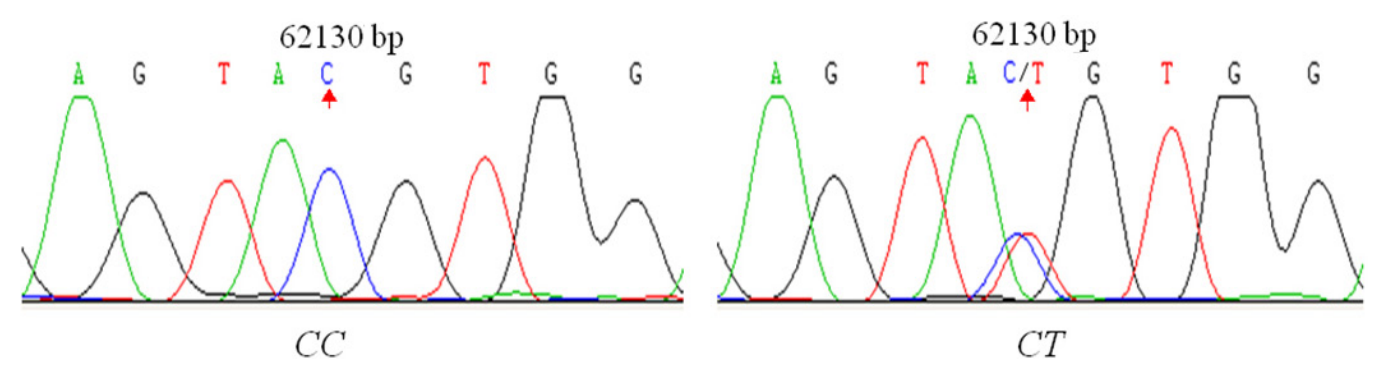

Figure 1. Sequencing maps of g.62130C $>$ T SNP in the 3 '-UTR of goat $P R L R$ gene. 


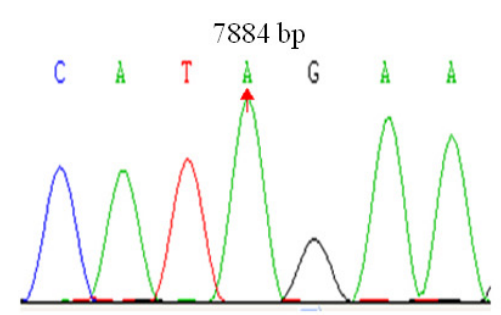

$A A$

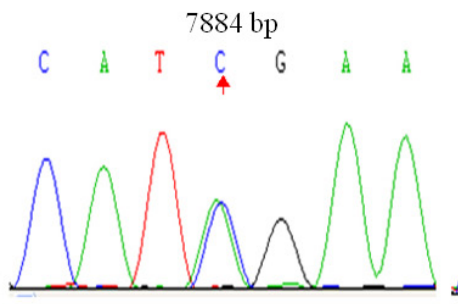

$A C$

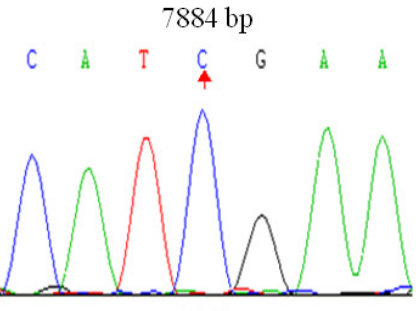

$C C$

Figure 2. Sequencing maps of g.7884A $>$ C SNP in the exon 3 of goat FOLR1 gene.

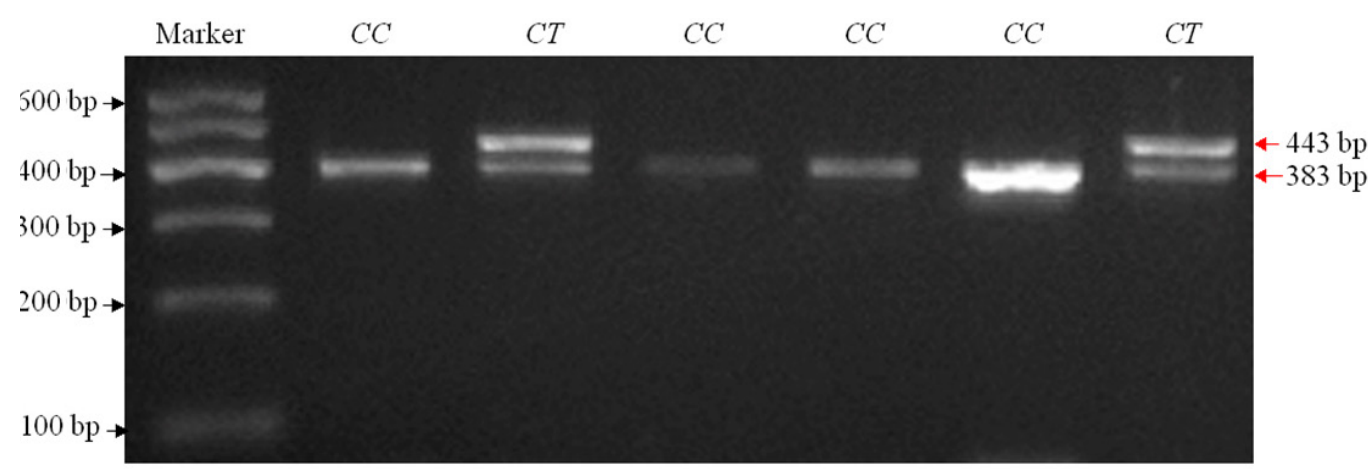

Figure 3. Electrophoresis patterns obtained after digestion with $R s a \mathrm{I}$ endonuclease at $g .62130 C>T$ locus. Fragments including $60 \mathrm{bp}$ of $\mathrm{CC}$ and $\mathrm{CT}$ genotypes were invisible.

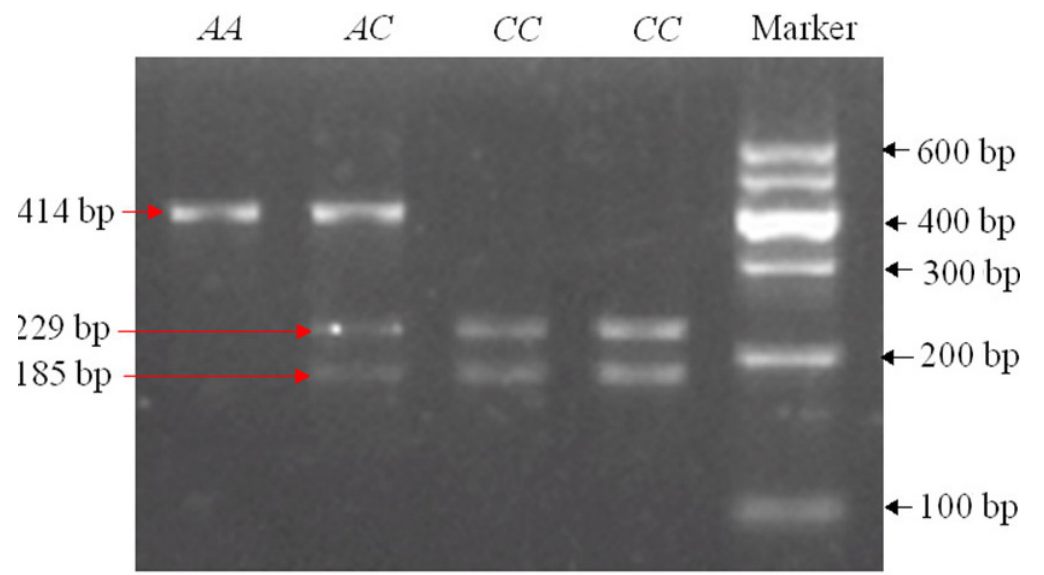

Figure 4. Electrophoresis patterns obtained after digestion with $S f a$ NI endonuclease at $g .7884 A>C$ locus.

\section{Association analysis of SNP with milk production traits}

In the SN breed, individuals with the $C C$ genotype had greater milk yield than those with the $C T$ genotype in the first, third, and average lactation at the g.62130C $>T$ locus $(\mathrm{P}<$ 0.05) (Table 3); in the GZ breed, individuals with $C C$ genotype had higher milk yield than those 
with the $C T$ genotype in the third and average lactation at the g.62130C $>T$ locus $(\mathrm{P}<0.05)$.

\section{Effects of allele substitution on microRNA sites}

The g.62130C $>$ T SNP in the 3'UTR of PRLR gene associated with production traits was analyzed for its potential effects on micro(mi)RNA binding sites. Analysis of miRNA sites in silico predicted that the g.62130C $>$ T SNP affects miRNA binding (Table 4). Both alleles of the g.62130C $>$ T SNP introduced several different miRNA sites, whereas the C allele introduced a miRNA binding site that was abrogated in the presence of the $\mathrm{T}$ allele.

\begin{tabular}{|c|c|c|c|c|c|c|}
\hline \multirow[t]{2}{*}{$\overline{\text { Locus }}$} & \multirow[t]{2}{*}{ Restriction enzyme } & & & \multicolumn{3}{|c|}{ Breed } \\
\hline & & & & SN & GZ & BG \\
\hline \multirow[t]{7}{*}{ g.62130C $>T$} & $R s a \mathrm{I}$ & Genotype & $C C$ & 215 & 145 & 112 \\
\hline & & & $C T$ & 108 & 52 & $\begin{array}{r}79 \\
79\end{array}$ \\
\hline & & Allele & $C$ & 0.83 & 0.87 & 0.79 \\
\hline & & & $T$ & 0.17 & 0.13 & 0.21 \\
\hline & & $\mathrm{H}_{\mathrm{E}}$ & & 0.33 & 0.26 & 0.41 \\
\hline & & PIC & & 0.24 & 0.20 & 0.27 \\
\hline & & Equilibrium $\chi^{2}$ test & & $\mathrm{P}<0.01$ & $\mathrm{P}=0.03$ & $\mathrm{P}<0.01$ \\
\hline \multirow{8}{*}{ g. $7884 A>C$} & $S f a \mathrm{NI}$ & Genotype & $C C$ & 323 & 197 & 59 \\
\hline & & & $A C$ & - & - & 119 \\
\hline & & & $A A$ & - & - & 13 \\
\hline & & Allele & $C$ & 1 & 1 & 0.62 \\
\hline & & & $A$ & 0 & 0 & 0.38 \\
\hline & & $\mathrm{H}_{\mathrm{F}}$ & - & - & - & 0.62 \\
\hline & & PIC & - & - & - & 0.36 \\
\hline & & Equilibrium $\chi^{2}$ test & - & - & - & $\mathrm{P}<0.01$ \\
\hline
\end{tabular}

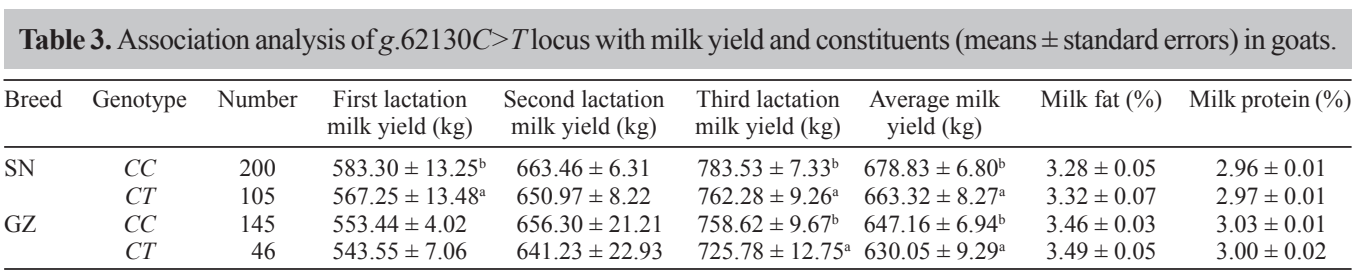

Values with different superscripts within the same column in particular population differ significantly at $\mathrm{P}<0.05$.

\section{Table 4 Effects of $P R L R$ 3'-untranslated region SNP on microRNA binding sites.}

\begin{tabular}{lcllr}
\hline SNP & Allele & miRNA name & miRNA sequence & Free energy $\Delta \mathrm{G}(\mathrm{kcal} / \mathrm{mol})$ \\
\hline g.62130C $>$ T & $\mathrm{C}$ & bta-miR-2317 & cucugugaugacaauaccugaua & -21.6 \\
& $\mathrm{C}$ & bta-miR-2324 & ugggguuggggcaguguggcugu & -24.1 \\
& $\mathrm{C}$ & bta-miR-302a & aagugcuuccauguuuuaguga & -20.6 \\
$\mathrm{~T}$ & bta-miR-2317 & cucugugaugacaauaccugaua & -21.6 \\
$\mathrm{~T}$ & bta-miR-2324 & ugggguuggggcaguguggcugu & -24.1 \\
\hline
\end{tabular}

\section{DISCUSSION}

The g.62130C $>T$ and $g .7884 A>C$ loci were in Hardy-Weinberg disequilibrium $(\mathrm{P}<$ $0.05)$, which showed that the genotypic frequencies had been affected by selection, muta- 
tion or migration. According to the classification of PIC (low polymorphism if PIC $<0.25$, moderate polymorphism if $0.25<$ PIC $<0.50$, and high polymorphism if PIC $>0.50$ ), the $\mathrm{SN}$ and GZ breeds at the $g .62130 C>T$ locus had low genetic diversity. The BG breed at the g. $7884 A>C$ locus had moderate genetic diversity. The identification of candidate genes that are responsible for variation in continuous traits or quantitative traits has been a challenge in modern genetics. So far, there have been some studies of the PRLR gene as a candidate gene in milk production traits in animals (Viitala et al., 2006; Lü et al., 2011a). Brym et al. (2005) reported that one SNP $(\mathrm{A} \rightarrow \mathrm{C})$ was found in the 205 nucleotide position of $P R L R$ intron 9 for Jersey and Polish Black-and-White cattle, respectively, and that Jersey cows of CC genotype produced more milk with higher protein content than those of $A A$ and $A C$ genotypes. Zidi et al. (2010) found that G401R (c.1201G $>$ A) and T452I (c.1355C $>$ T) amino acid substitutions were associated with milk composition traits in a Murciano-Granadina goat population. Previous studies in dairy cattle demonstrated six amino acid substitutions within the signal peptide and extracellular domains of PRLR, including two polymorphisms (K2F and S18N) in exon 3 and four (L186P, S208C, R225Q, and L226I) in exon 7 (Viitala et al., 2006; Scotti et al., 2007; Zhang et al., 2008), which were significantly associated with milk production traits in Finnish Ayrshire and Holstein cattle breeds. Two newly detected SNPs (g.9206G $>$ A and g.9681C $>$ T) caused amino acid variations E378K and A536V, respectively, which were significantly associated with milk yields, and cows with the combined genotype $G G C C$ showed superior milk performance (Lü et al., 2011b). In this study, the g.62130C $>T$ SNP was located in the 3'-UTR, but the results showed that it was associated with milk yield in the SN and GZ breeds. The reason could be that the $\mathrm{C}$ allele at the $g .62130 C>T$ locus introduced a miRNA site for btamiR-302a. Limited information is available on the effects of the introduction or abrogation of miRNA binding sites on genes involved in growth, postnatal development, and production traits in cattle. However, miRNA are well established as posttranscriptional gene expression regulators and are thought to regulate as many as 5300 human genes (Lewis et al., 2005). The biochemical and physiological functions, together with the results obtained in our study, indicate that the SNP (g.62130C $>$ T) associated with milk performance has potential applications in a marker-assisted selection program for dairy goat breeding.

\section{CONCLUSIONS}

The g.62130C $>$ T SNP in the goat PRLR gene had significant effects on milk production traits. In addition, the present study showed it to be a genetic marker for goat genetics and breeding, with potential applications in breeding programs.

\section{ACKNOWLEDGMENTS}

Research supported by the National Support Program of China (\#2011BAD28B05-3) and the Science and Technology Innovation Project of Shaanxi Province (\#2011KTCL02-09).

\section{REFERENCES}

Bansal A, van den Boom D, Kammerer S, Honisch C, et al. (2002). Association testing by DNA pooling: an effective initial screen. Proc. Natl. Acad. Sci. U. S. A. 99: 16871-16874.

Bole-Feysot C, Goffin V, Edery M, Binart N, et al. (1998). Prolactin (PRL) and its receptor: actions, signal transduction 
pathways and phenotypes observed in PRL receptor knockout mice. Endocr. Rev. 19: 225-268.

Brym P, Kamiński S and Wójcik E (2005). Polymorphism within the bovine prolactin receptor gene (PRLR). Anim. Sci. Pap. Rep. 23: 61-66.

Chu MX, Mu YL, Fang L, Ye SC, et al. (2007). Prolactin receptor as a candidate gene for prolificacy of small tail han sheep. Anim. Biotechnol. 18: 65-73.

Clevenger CV, Freier DO and Kline JB (1998). Prolactin receptor signal transduction in cells of the immune system. $J$. Endocrinol. 157: 187-197.

Clevenger CV and Kline JB (2001). Prolactin receptor signal transduction. Lupus 10: 706-718.

Fontanesi L, Scotti E, Dolezal M, Lipkin E, et al. (2007). Bovine chromosome 20: milk production QTL and candidate gene analysis in the Italian Holstein-Friesian breed. Ital. J. Anim. Sci. 6: 133-135.

Ghaffariyan S, Mohammadi SA and Aharizad S (2012). DNA isolation protocol for the medicinal plant lemon balm (Melissa officinalis, Lamiaceae). Genet. Mol. Res. 11: 1049-1057.

Hayes H, Le Chalony C, Goubin G, Mercier D, et al. (1996). Localization of ZNF164, ZNF146, GGTA1, SOX2, PRLR and EEF2 on homoeologous cattle, sheep and goat chromosomes by fluorescent in situ hybridization and comparison with the human gene map. Cytogenet. Cell Genet. 72: 342-346.

Iso-Touru T, Kantanen J, Li MH, Gizejewski Z, et al. (2009). Divergent evolution in the cytoplasmic domains of PRLR and GHR genes in Artiodactyla. BMC Evol. Biol. 9: 172.

Leamon CP and Jackman AL (2008). Exploitation of the folate receptor in the management of cancer and inflammatory disease. Vitam. Horm. 79: 203-233.

Lewis BP, Burge CB and Bartel DP (2005). Conserved seed pairing, often flanked by adenosines, indicates that thousands of human genes are microRNA targets. Cell 120: 15-20.

Lü A, Hu X, Chen H, Dong Y, et al. (2011a). Single nucleotide polymorphisms of the prolactin receptor (PRLR) gene and its association with growth traits in Chinese cattle. Mol. Biol. Rep. 38: 261-266.

Lü A, Hu X, Chen H, Dong Y, et al. (2011b). Novel SNPs of the bovine PRLR gene associated with milk production traits. Biochem. Genet. 49: 177-189.

Menzies KK, Lefevre C, Sharp JA, Macmillan KL, et al. (2009). A novel approach identified the FOLR1 gene, a putative regulator of milk protein synthesis. Mamm. Genome 20: 498-503.

Ross JF, Chaudhuri PK and Ratnam M (1994). Differential regulation of folate receptor isoforms in normal and malignant tissues in vivo and in established cell lines. Physiologic and clinical implications. Cancer 73: 2432-2443.

Rusinov V, Baev V, Minkov IN and Tabler M (2005). MicroInspector: a web tool for detection of miRNA binding sites in an RNA sequence. Nucleic Acids Res. 33: W696-W700.

Santos EM, Paula JF, Motta PM, Heinemann MB, et al. (2010). Comparison of three methods of DNA extraction from peripheral blood mononuclear cells and lung fragments of equines. Genet. Mol. Res. 9: 1591-1598.

Scotti E, Fontanesi L and Russo V (2007). Mutations in the bovine prolactin receptor (PRLR) gene: allele and haplotype frequencies in the Reggiana cattle breed. Ital. J. Anim. Sci. 6: 207.

Terman A (2005). Effect of the polymorphism of prolactin receptor (PRLR) and leptin (LEP) genes on litter size in Polish pigs. J. Anim. Breed. Genet. 122: 400-404.

Tian Y, Wu G, Xing JC, Tang J, et al. (2012). A novel splice variant of folate receptor 4 predominantly expressed in regulatory T cells. BMC Immunol. 13: 30 .

Viitala S, Szyda J, Blott S, Schulman N, et al. (2006). The role of the bovine growth hormone receptor and prolactin receptor genes in milk, fat and protein production in Finnish Ayrshire dairy cattle. Genetics 173: 2151-2164.

Zhang JL, Zan LS, Fang P, Zhang F, et al. (2008). Genetic variation of PRLR gene and association with milk performance traits in dairy cattle. Can. J. Anim. Sci. 88: 33-39.

Zhou JP, Zhu XP, Zhang W, Qin F, et al. (2011). A novel single-nucleotide polymorphism in the 5' upstream region of the prolactin receptor gene is associated with fiber traits in Liaoning cashmere goats. Genet. Mol. Res. 10: 2511-2516.

Zidi A, Serradilla JM, Jordana J, Carrizosa J, et al. (2010). Pleiotropic effects of the goat prolactin receptor genotype on milk fatty acid composition. Domest. Anim. Endocrinol. 39: 85-89. 